University of Nebraska - Lincoln

DigitalCommons@University of Nebraska - Lincoln

Faculty Publications, Department of History

History, Department of

January 2005

\title{
Maternal Colonialism: White Women and Indigenous Child Removal in the American West and Australia, 1880-1940
}

Margaret D. Jacobs

University of Nebraska - Lincoln, mjacobs3@unl.edu

Follow this and additional works at: https://digitalcommons.unl.edu/historyfacpub

Part of the History Commons

Jacobs, Margaret D., "Maternal Colonialism: White Women and Indigenous Child Removal in the American West and Australia, 1880-1940" (2005). Faculty Publications, Department of History. 11.

https://digitalcommons.unl.edu/historyfacpub/11

This Article is brought to you for free and open access by the History, Department of at DigitalCommons@University of Nebraska - Lincoln. It has been accepted for inclusion in Faculty Publications, Department of History by an authorized administrator of DigitalCommons@University of Nebraska - Lincoln. 


\title{
Maternal Colonialism: White Women and Indigenous Child Removal in the American West and Australia, i 880-I 940
}

\author{
Margaret D. Jacobs
}

\begin{abstract}
This study of white women's involvement in the removal of indigenous children in a comparative, international context offers an opportunity for recasting the history of women and gender in the American West as part of a larger story of gender and settler colonialism around the globe.
\end{abstract}

Between 1898 and 1910, when social reformer Estelle Reel worked as superintendent of Indian education for the Office of Indian Affairs, she often penned self-promoting articles in the third person that were later syndicated in newspapers across the country. In one such article, "Woman's Great Work for the Government," she claimed:

Miss Reel is popular with the Indians. She is known as the "Big White Squaw from Washington." So fond of her are some of the Indians that they are willing she should take their children away, and one Indian woman insisted that she should carry a pair of fat papooses to President Roosevelt. She doesn't have to bribe the Indians with promises and presents to send their children to school now. ${ }^{1}$

Reel's upbeat article coincided with her efforts during her first years in office to pass a compulsory education law that would have removed most Indian chil-

Margaret D. JaCobs, associate professor of history at the University of Nebraska-Lincoln, thanks the National Endowment for the Humanities, the Fulbright Program, the Charles Redd Center, and the Southwest and Border Cultures Institute at New Mexico State University for funding research.

1 "Woman's Great Work for the Government," draft of article, n.d., "Articles" folder, box 1, Estelle Reel Papers, H6-110, Wyoming State Archives, Cheyenne, WY [hereafter Reel Papers, WSA].

Western Historical Quarterly 36 (Winter 2005): 453-476. Copyright (C) 2005, Western History Association. Used by permission.

Online @ http://www.historycooperative.org/journals/whq/36.4/jacobs.html 
dren from their homes and communities and required them to attend boarding schools. Like many white women reformers of her time who worked with Indian peoples in the American West, she regarded it as her maternalistic duty to rescue indigenous children from what she considered a savage background and to raise them instead in a "civilized" environment.

Reel's efforts illuminate a neglected area of study in the history of gender and women in the American West. White women, primarily as reformers, but also as teachers and administrators, were integrally involved in promoting, carrying out, and sometimes challenging the removal of American Indian children to boarding schools. They also contributed to the racialized and gendered representations of Indian peoples that made such policies possible. White women reformers in the American West, however, were not alone in promoting the removal and institutionalization of indigenous children.

Consider that in Australia in 1929 itinerant missionary Annie Lock explained to her sister reformer, Constance Cooke, "We are trying to solve the problem with the natives up this way [in the Northern Territory]. The only thing I can see would [be] to get the children right away from their parents and teach them good moral, clean habits \& right from wrong $\&$ also industries that will make them more useful $\&$ better citizen[s] by $\&$ by." Like Reel, Lock declared: "The parents are willing to give them over to me." Australia too, white women reformers believed it their special province to "save" indigenous children by removing them from their families.

Studying white women's involvement in the removal of indigenous children in a comparative, international context offers an opportunity for recasting the history of women and gender in the American West as part of a larger story of gender and settler colonialism around the globe. The potential value of such comparative history, is that it may, in the words of George Fredrickson, "jolt historians out of accustomed ways of thinking about their original areas of specialization and enable them to look at the familiar in a new way." 3

Indeed, even the use of the term "removal" may seem jolting to historians of Indian boarding schools. After decades of significant research on the schools, we have moved far away from seeing the schools as simply an oppressive mechanism of state authority. Now scholars have created a complex portrait of the schools and Indian families' experiences of them that emphasizes Native agency, not government con-

${ }^{2}$ Annie Lock to Constance Cooke, 18 September 1929, Government Record Group 52/32/32, State Records of South Australia, Adelaide, AUS [hereafter GRG, record number, SRSA].

${ }^{3}$ George M. Fredrickson, The Comparative Imagination: On the History of Racism, Nationalism, and Social Movements (Berkeley, CA, 1997), 67. 
trol. ${ }^{4}$ While this more nuanced scholarship on Indian boarding schools is welcome, a comparison of policies toward indigenous children in the American West and Australia shifts our attention away from the schools per se to the promotion of widespread indigenous child removal by state authorities. How did such a drastic solution-the systematic and wholesale separation of indigenous children from their families and communities-become thinkable, let alone put into practice?

An emphasis on white women as agents of colonial control in the American West may also be jarring in a field that has been so focused on westering white women's triumphs and tribulations. Yet failure to examine white women as more than hearty pioneers, innocent bystanders to colonial conquest, has left the field of western women's history in a Turnerian rut. While many other western historians have grappled with "the legacy of conquest," white women have remained largely immune from such scrutiny, with a few notable exceptions. ${ }^{5}$ This essay thus represents an attempt to budge the field of western women's history from its well-trodden trail.

Colonial officials and settlers in the American West and Australia not only appropriated the land, labor, and resources of indigenous inhabitants, but also sought to dispossess them of their children. This colonial practice involved an invasion into the most intimate spaces and relationships of indigenous people's lives. It was through these "intimacies of empire," as Ann Laura Stoler calls them, that "racial classifications were defined and defied, where relations between colonizer and colonized could powerfully confound or confirm the strictures of governance and the categories of rule." Indeed, in justifying and carrying out the removal of indigenous children from their families and communities, officials and reformers on opposite shores of the Pa-

${ }^{4}$ Brenda J. Child, Boarding School Seasons: American Indian Families, 1900-1940 (Lincoln, NE, 1998); K. Tsianina Lomawaima, They Called it Prairie Light: The Story of the Chilocco Indian School (Lincoln, NE, 1994); Clyde Ellis, To Change Them Forever: Indian Education at the Rainy Mountain Boarding School, 1893-1920 (Norman, OK, 1996); Scott Riney, The Rapid City Indian School, 1898-1933 (Norman, OK, 1999); Michael C. Coleman, American Indian Children at School, 1850-1930 (Jackson, MS, 1993).

${ }^{5}$ Peggy Pascoe's Relations of Rescue: The Search for Female Moral Authority in the American West, 1874-1939 (New York, 1990) and Linda Gordon's The Great Arizona Orphan Abduction (Cambridge, MA, 1999) represent two recent works that do examine white women's roles in shaping racial ideologies and enacting colonial power relations in the American West.

${ }^{6}$ Ann Laura Stoler, "Tense and Tender Ties: The Politics of Comparison in North American History and (Post) Colonial Studies," Journal of American History 88 (December 2001): 830. See also, Ann Laura Stoler, Carnal Knowledge and Imperial Power: Race and the Intimate in Colonial Rule (Berkeley, CA, 2002); Margaret Strobel, Gender, Sex, and Empire (Washington, DC, 1994); Julia Clancy-Smith and Frances Gouda, eds., Domesticating the Empire: Race, Gender, and Family Life in French and Dutch Colonialism (Charlottesville, VA, 1998). 
cific often employed a common racial discourse and developed a ubiquitous set of racialized representations of indigenous people. ${ }^{7}$

Moreover, unlike more masculine terrains of colonialism, removal and institutionalization of indigenous children was largely a feminine domain, defined primarily around mothering, particularly targeted at indigenous women, and implemented largely by white women. Government authorities and reformers relied not only on racial representation, but also on gendered images of indigenous people, particularly regarding motherhood, as a justification for intervening in the intimate spaces of indigenous communities. Furthermore, to carry out a policy of indigenous child removal, male policymakers often enlisted white women. Desirous of overcoming their own marginalized status, many white women embraced the opportunity to participate in the colonial project. ${ }^{8}$ In fact, they claimed, based on their own association with motherhood, a particular aptitude for carrying out "women's work for women." Yet, white women did not always behave in the scripted ways assigned to them by government officials; often, in fact, they challenged their government's handling of indigenous children, if not often the overall policy of child removal. As in other colonial settings, many white women developed an ambivalence toward their nation's colonial projects. While they enjoyed racial and colonial privilege, they also endured gender exclusion; their uneven status enabled them to simultaneously collaborate with and confound colonial aims. ${ }^{10}$

Of course indigenous women also complicated both the intentions of colonial authorities and the ambitions of white maternalists. Their experiences of and perspectives regarding white women's intervention into their families are an essential element

\footnotetext{
${ }^{7}$ Margaret D. Jacobs, "Indian Boarding Schools in Comparative Perspective: The Removal of Indigenous Children in the U.S. and Australia, 1880-1940," in Boarding School Blues: Revisiting the American Indian Boarding School Experience, ed. Clifford Trafzer and Jean Keller (Lincoln, NE, forthcoming).

${ }^{8}$ This was true in other contexts as well. See, for example, Antoinette M. Burton, Burdens of History: British Feminists, Indian Women, and Imperial Culture, 1865-1915 (Chapel Hill, NC, 1994). For the association of American feminism with imperialism, see Louise Michelle Newman, White Women's Rights: The Racial Origins of Feminism in the United States (New York, 1999).

${ }^{9}$ This phrase turns up frequently in the writing of women reformers. As just one example, see Helen Gibson Stockdell, "Woman's Work for Women on the Lemhi Reservation," The Woman's Auxiliary 67 (January 1902): 53-4, box 64, Archives of the Episcopal Diocese of Idaho, MSS 91, Special Collections, Boise State University, ID.

${ }^{10}$ See Fiona Paisley, "Introduction, White Settler Colonialisms and the Colonial Turn: An Australian Perspective," Journal of Colonialism and Colonial History 4 (Winter 2003): 10; Nupur Chaudhuri and Margaret Strobel, eds., Western Women and Imperialism: Complicity and Resistance (Bloomington, IN, 1992); Kumari Jayawardena, The White Woman's Other Burden: Western Women and South Asia during British Colonial Rule (New York, 1995).
} 
in understanding these intimacies of empire. By providing an in-depth examination of white women's role in child removal, however, this article could not do justice to indigenous women's experiences of removal. I offer here only a glimpse into their viewpoints, but will return to their accounts in future writings.

Before delving into white women's role in indigenous child removal, a brief comparison of colonialism in the American West and Australia may be helpful. In both regions, a distinctive kind of settler colonialism developed that Patrick Wolfe defines as "first and foremost a territorial project. Land is its primary object and governing motive." Thus "its aim is the replacement of native society.... its governing logic is one of elimination." 11 Certainly the first century of settlement in the American West and Australia — at roughly the same time from the late-eighteenth through the nineteenth centuries - was marked by the elimination of indigenous peoples through dispossessing them of their lands, outright violence, destruction of habitat and traditional food supplies, and the introduction of European diseases.

After these "cataclysmic events," as Wolfe writes, "the survivors ... generally proved an affront to the sensibilities of respectable colonists." ${ }^{2}$ Attempts to confine indigenes to reservations in the American West and to missions and small government reserves in Australia failed to successfully segregate them from settlers. In the case of the American West, violent conflict continued between incoming settlers and Indians who refused to recognize the new boundaries of their reservations. In Australia, officials could not prevent the continued sexual contact between Aboriginal women and European men or the resulting mixed-race progeny.

Beginning in the late-nineteenth century, Australian colonial authorities began to develop separate policies for so-called "full-blood" Aborigines and "half-castes." Believing that "full-blood" Aborigines were dying out, officials sought to isolate them on remote reserves. By contrast, Australian administrators claimed "half-castes," whose numbers were increasing, to be a "menace" and a "burden" to the social order. Government officials thus proposed that "half-castes" should be "absorbed" into the white population, and identified the removal of part-Aboriginal children to institutions as a primary means to achieve their ends. Some chief protectors of Aborigines, including Cecil Cook in the Northern Territory and A. O. Neville in Western Australia, even

${ }^{11}$ Patrick Wolfe, Logics of Elimination: Colonial Policies on Indigenous Peoples in Australia and the United States, text of public lecture delivered at University of Nebraska, 21 February 1999 (Lincoln, NE, 2000), 2. See also, Wolfe, "Land, Labor, and Difference: Elementary Structures of Race," American Historical Review 106 (June 2001): 872.

${ }^{12}$ Wolfe, Logics of Elimination, 5. 


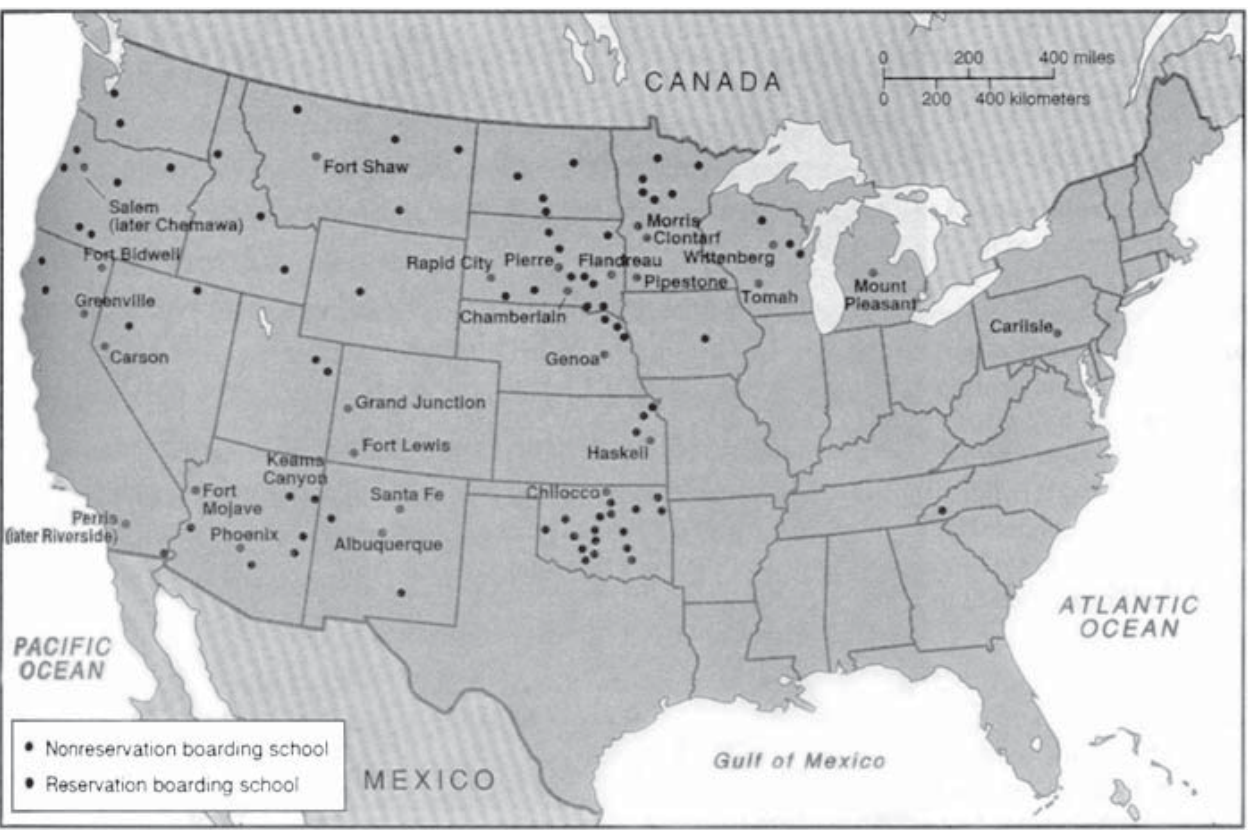

In WHQ's winter issue 2005 print version, this map was erroneously attributed to Francis Paul Prucha's Atlas of American Indian Affairs (Lincoln: University of Nebraska Press, 1990). The map, which was adapted — with several changes-from Prucha's work, actually came from Colin G. Calloway's, The First Peoples: A Documentary Survey of American Indian History (Boston: BedfordSt.Martin’s 2004), 345. An erratum appears in the spring 2006 print issue of WHQ.

favored "breeding out the colour" of Aborigines through removing "half-caste" girls from their families and carefully arranging their marriages to white men. ${ }^{13}$

By 1911, every Australian state except Tasmania had enacted legislation allowing for the forcible removal of indigenous children to homes and missions, some established by religious organizations, others operated by state governments. These policies also included programs for "apprenticing" teenaged Aborigines, the boys to work in manual labor, the girls as domestic servants. Many authorities particularly targeted lighter-skinned Aboriginal girls for removal and intended to permanently separate children from their families and communities. Today, Aboriginals who were subjected to this policy are commonly known in Australia as "the Stolen Generations." 14

${ }^{13}$ Please note that the title "chief protectors" and other words and phrases would, in Australian journals, be capped. For more on Neville, see Quentin Beresford and Paul Omaji, Our State of Mind: Racial Planning and the Stolen Generations (Fremantle, AUS, 1998), 30-55. For more on Cook, see Russell McGregor, Imagined Destinies: Aboriginal Australians and the Doomed Race Theory, 1880-1939 (Melbourne, AUS, 1997), 153, 155-6, 167-73.

14 The literature on the Stolen Generations is vast. Two overviews include Human Rights and Equal Opportunity Commission, Bringing Them Home: Report of the National Inquiry into the Separation of Aboriginal and Torres Strait Islander Children from their Families (Sydney, AUS, 1997) and Anna Haebich, Broken Circles: Fragmenting Indigenous Families 1800-2000 (Fremantle, AUS, 2000). 
In the American West, it was neither widespread sexual contact between EuroAmerican men and Indian women nor the resulting mixed-race children that alarmed authorities. Instead it was decades of costly Indian wars that drove government authorities to recommend assimilation and the removal of Indian children to boarding schools as the means to solve, once and for all, the so-called "Indian problem." After Captain Richard Henry Pratt established the Indian boarding school, Carlisle Institute, in Pennsylvania in 1879 to assimilate Indian children, the federal government began to promote boarding schools, and the removal of large numbers of Indian children to them, as a key element of its assimilation policy. ${ }^{15}$

By 1900, the government had opened about 150 boarding schools (as well as another 150 day schools) for about 21,500 Native American children. ${ }^{16}$ Religious organizations also operated institutions for Native children, sometimes through contracts with the government. As in Australia, institutional authorities created a special "outing" program that placed older children among white families as laborers and servants for part of each day and during the summers. Officials sought to remove every Indian child to a boarding school for a period of at least three years. While some officials questioned this policy or revised it slightly in the first decade of the 1900s and in the 1920s, it was not until John Collier's administration of the Bureau of Indian Affairs (BIA) in the 1930s that the policy was overturned, if only briefly. ${ }^{17}$

The chronological scope of this article is limited to the pre-World War II years in which institutionalization was a common feature of indigenous child removal. After World War II, authorities in both the U. S. and Australia continued to remove indigenous children from their families, more commonly to be fostered in or adopted by white families.

Although both nations developed similar strategies of removing indigenous children in order to control indigenous populations, there seems to be little evidence of any direct influence of one country upon the other. U. S. officials and reform-ers did not cite other countries as examples or models for their policy, although they did

${ }^{15}$ Richard Henry Pratt, Battlefield and Classroom; Four Decades with the American Indian, 1867-1904, ed. Robert M. Utley (New Haven, CT, 1964).

${ }^{16}$ David Wallace Adams, Education for Extinction: American Indians and the Boarding School Experience, 1875-1928 (Lawrence, KS, 1995), 57-8.

${ }^{17}$ For more on the boarding schools, see Adams, Education for Extinction; Child, Boarding School Seasons; Lomawaima, They Called it Prairie Light; Ellis, To Change Them Forever; Riney, The Rapid City Indian School; Coleman, American Indian Children; Margaret L. Archuleta, Brenda J. Child, and K. Tsianina Lomawaima, eds., Away from Home: American Indian Boarding School Experiences, 1879-2000 (Phoenix, AZ, 2000); Robert A. Trennert, Jr., The Phoenix Indian School: Forced Assimilation in Arizona, 1891-1935 (Norman, OK, 1988). 
draw parallels between their policies toward Indians and toward "dependent peoples" in other U. S. colonies such as Puerto Rico, Hawaii, and the Philippines. ${ }^{18}$

Australian authorities did discuss racial policies in other countries, but in a very general sense. At a 1929 Royal Commission on the Constitution of Australia, for example, one delegate questioned a reformer as to whether he was aware of the "American coloured problem." The reformer replied "I know that a mixture of races often produces unhappy results." 19 Interestingly, concerned as they were with the "halfcaste menace," it was the specter of "miscegenation" between white and black Americans, not the American government's treatment of American Indians, that Australians looked to as a lesson in colonial race relations.

What accounts, then, for the common colonial strategy in both locations of separating children from their parents? Certainly there were many historical precedents for such a practice, from Spanish colonizers in sixteenth-century Peru who established a convent for mixed-race girls to slaveholders who separated or threatened to separate slave children from their families. ${ }^{20}$ The removal of children also became a ubiquitous practice of state authorities in dealing with working-class families in urban areas in the nineteenth century in many countries, including both Australia and the United States. ${ }^{21}$ Thus, perhaps it is not surprising that although the United States and Australia were truly on opposite sides of the world, they nevertheless both turned to the removal of indigenous children as a primary means to control indigenous populations.

As government authorities in both the United States and Australia moved toward adopting indigenous child removal as state policy, many white middle-class women in both nations became involved in advocating for indigenous women, largely with-

${ }^{18}$ Historians of American Indians are very familiar with the Lake Mohonk Conference of the Friends of the Indian, a group of reformers that met annually to discuss Indian reform from 1883 onward. The full title of their annual reports and proceedings, Lake Mohonk Conference of the Friends of the Indian and Other Dependent Peoples, and their attendant discussions of Puerto Ricans, Hawaiians, Filipinos, and other newly "dependent peoples," demonstrates that for many reformers the two issues of imperialism abroad and assimilation within were intimately connected. See also, Matthew Frye Jacobson, Barbarian Virtues: The United States Encounters Foreign Peoples At Home and Abroad, 1876-1917 (New York, 2000).

${ }^{19}$ Testimony of Charles E.C. Lefroy, in Parliament of the Commonwealth of Australia, Report of the Royal Commission on the Constitution (Canberra, AUS, 1929), 479.

${ }^{20}$ Kathryn Burns, Colonial Habits: Convents and the Spiritual Economy of Cuzco, Peru (Durham, NC, 1999) and Deborah Gray White, Ar'n't I a Woman?: Female Slaves in the Plantation South (New York, 1985).

${ }^{21}$ Susan Tiffin, In Whose Best Interest?: Child Welfare Reform in the Progressive Era (Westport, CT, 1982). Jan McKinley Wilson's “'You Took our Children': Aboriginal Autobiographical Narratives of Separation in New South Wales, 1977-1997" (PhD diss., Australian National University, 2001), 60-7, traces state policies of separating Aboriginal children from their families in New South Wales to earlier state policies regarding "neglected" working-class children. 
out any input whatsoever from indigenous women themselves. In the United States in 1879, these white women established the Women's National Indian Association (WNIA), which played an influential role in persuading the government to adopt an assimilation policy, and they continued to campaign for American Indian women well into the twentieth century. ${ }^{22}$ In Australia in the first decades of the twentieth century, white women promoted the absorption of Aboriginal people and crusaded to gain more influence over Aboriginal affairs, particularly through the Woman's Christian Temperance Union, the Women's Non-Party Association, and the Women's Service Guilds. ${ }^{23}$

To counter notions that women should remain within the home, middle-class white women often justified their public activism by invoking their traditional roles or potential capabilities as mothers, an ideology that many women's historians have dubbed "maternalism." ${ }^{24}$ Missionary as well as feminist publications at the turn of the twentieth century are filled with paeans to motherhood. Ellen Key, a Swedish feminist thinker who was influential in both the United States and Australia, for example, asserted that " $[\mathrm{t}]$ he time will come in which the child will be looked upon as holy ... ; a time in which all motherhood will be looked upon as holy, if it is caused by a deep emotion of love, and if it has called forth deep feelings of duty." 25

White maternalists asserted the need for motherly values—what Australian Bessie Rischbieth called the "mother voice" - to be extended beyond the home into society to uplift women and children of other races and classes whom white maternalists believed to be oppressed. Hannah Schoff, president of the National Congress of Mothers in the U. S., wrote in 1905: "There is a broader motherhood than the motherhood that mothers one's own; there is the spirit of the Lord that is the mother that

22 See Margaret D. Jacobs, Engendered Encounters: Feminism and Pueblo Cultures, 1879-1934 (Lincoln, NE, 1999); Valerie Sherer Mathes, "Nineteenth Century Women and Reform: The Women's National Indian Association," American Indian Quarterly 14 (Winter 1990): 1-18; Helen M. Wanken, "'Woman's Sphere' and Indian Reform: The Women's National Indian Association, 1879-1901” (PhD diss., Marquette University, 1981).

${ }^{23}$ See Fiona Paisley, Loving Protection?: Australian Feminism and Aboriginal Women's Rights, 1919-1939 (Carlton South, AUS, 2000) and Alison Holland, "'Saving the Aborigines,' The White Woman's Crusade: A Study of Gender, Race, and the Australian Frontier, 1920s-1960s" (PhD diss., University of New South Wales, 1998).

${ }^{24}$ For some of the literature on maternalism, see Karen Anderson, "Changing Woman: Maternalist Politics and 'Racial Rehabilitation' in the U. S. West," in Over the Edge: Remapping the American West, ed. Valerie J. Matsumoto and Blake Allmendinger (Berkeley, CA, 1999), 148-59; Linda Gordon, Pitied But Not Entitled: Single Mothers and the History of Welfare, 1890-1935 (Cambridge, MA, 1994); Molly Ladd-Taylor, Mother-Work: Women, Child Welfare, and the State, 1890-1930 (Urbana, IL, 1994).

${ }^{25}$ Ellen Karolina Sofia Key, The Century of the Child (1909; reprint, New York, 1972), 44. 
mothers all children, and it is because the world lacks that, that the conditions of the children of this country have not been better." 26

White maternalists on both sides of the Pacific parlayed this worldly motherhood into a program to mother indigenous women and their children. In 1890, WNIA member Mrs. Dorchester asserted that "[n]o uncivilized people are elevated till the mothers are reached. The civilization must begin in the homes." ${ }^{27}$ Maternalists contended that white women were better suited to carry out such "women's work for women" than their male counterparts. Australian reformer Edith Jones, for example, argued that white women "can understand ... [the] needs [of Aboriginal women and children] far better than men, however kindly disposed they may be." 28

Since white women reformers regarded motherhood as a sacred institution and the mother-child bond as a holy relationship, one might expect to find such women in opposition to removing indigenous children to institutions. Instead, many white women reformers agreed with Dorothea Rueford in Australia that for "half-castes," the "only hope of redemption as a class lies in their children. Would we be justified in taking these children and having them adequately educated and trained in some skill—compulsorily if necessary? This compulsory taking away of children is distasteful to most of us but it seems the only course open and should only be necessary for one generation." ${ }^{29}$ On the American side, most women reformers in the late-nineteenth and early-twentieth centuries supported the position of Estelle Reel that "the Indian child must be placed in school before the habits of barbarous life have become fixed, and there he must be kept until contact with our life has taught him to abandon his savage ways and walk in the path of Christian civilization." 30

White women maternalists on both sides of the Pacific justified the "rescue" of indigenous children by focusing on the perceived differences and deficiencies of indigenous women. First, they portrayed indigenous women as the powerless drudges of their men. Helen Gibson Stockdell, a missionary for the Trinity Mission at Lemhi Indian Agency in Idaho, believed that Indian women "make slaves of themselves for the

${ }^{26}$ Quoted in Elizabeth Rose, A Mother's Job: The History of Day Care 1890-1960 (New York, 1999), 2.

27 The Indian's Friend 2 (July 1890): 2.

${ }^{28}$ Conference of Representatives ... to consider the Report ... by J.W. Bleakley, 12 April 1929, p. 41, Commonwealth Record Series A1/15, 33/8782, Australian National Archives, Canberra, Australian Capital Territory, AUS [hereafter CRS, record number, NA ACT].

${ }^{29}$ Report by Dorothea Rueford, n.d., item 196, box 30, series 12, Bessie Rischbieth Papers, MS 2004, National Library of Australia [hereafter, NLA], Canberra, AUS [hereafter, Rischbieth Papers].

30 “Her Work for the Indians," n.d., “Articles” folder, box 1, Reel Papers, WSA. 
men."31 Daisy Bates, a famous early Australian anthropologist who lived for decades among Aboriginal peoples, echoed this sentiment regarding Aborigines, declaring, "All of their laws were formed for the convenience and well-being of the men only ... every little girl learns from her young childhood the law of slavish obedience to the men and boys in her group."32

Sexual and marriage practices among indigenous groups particularly disturbed white women. In Alaska, for example, the WNIA alleged, "girls from a few months old and upward are sold as wives," and "girls from 10 to 15 years of age are rented by their parents to white men." 33 An Australian reformer bemoaned the practice of arranging marriages between older men and young Aboriginal girls, who "having committed the crime of being born girls are foredoomed to give their clean little bodies to dirty old men in the bush who can claim them by native right." ${ }^{34}$ Many white women reformers believed it was essential to remove indigenous children, particularly girls, from their families to protect them from what white women perceived to be sexual exploitation and abuse.

White women reformers also commonly portrayed indigenous women as sexually immoral. In a typical comment, Amelia Stone Quinton, the WNIA's president, claimed that Navajo women were promiscuous and therefore "good morals are next to impossible. For children from such homes, the day school can do far less than the boarding school." ${ }^{35}$ Ernestine Hill, a journalist in Australia, asserted: "The black woman understands only sex, and that she understands fairly well. She is easy for the taking." Hill added that an Aboriginal woman "has no moral ethics whatever." ${ }^{36}$

Other white women claimed that indigenous women did not know how to properly care for their children. Annie Lock criticized Aboriginal women at Ooldea for being "very careless with their babies [who] were sleeping cosy in my arms \& cried when their mothers took them, they carry them so uncomfortable [sic]." ${ }^{37}$ One American missionary, Miss Howard, believed Indian women were misguided in their

${ }^{31}$ Stockdell, "Woman's Work for Women on the Lemhi Reservation," 53-4.

32 "Suggestions for the Betterment of Aborigines and Castes," 1939, folio 65/4, box 33, Daisy Bates Papers, MS 365, NLA. See also, Patricia Grimshaw, Colonialism, Gender and Representations of Race: Issues in Writing Women's History in Australia and the Pacific (Parkville, AUS, 1994).

33 The Indian's Friend 1 (March 1889).

34 “The Australian Aborigine Woman: Is She a Slave?" n.d. [ca. 1930], item 316, box 31, series 12, Rischbieth Papers.

35 The Indian's Friend 3 (June 1891).

36 The Great Australian Loneliness (1940; reprint, Melbourne, AUS, 1952), 230, 231.

${ }^{37}$ Quoted in Catherine E. Bishop, “'a woman missionary living amongst naked blacks': Annie Lock, 1876-1943” (master's thesis, Australian National University, 1991), 76. 
use of cradle boards. "I found a woman with a sick baby not yet three weeks old," she wrote. "Of course it was strapped upon a board; and it was moaning with fever." Howard believed the WNIA "would do a good work if we accomplished only [the cradle board's] abolition." 38

Reformers also implied that indigenous women did not provide a proper home for the upbringing of their children. Violet Turner, a writer who detailed the work of Annie Lock, described one Aboriginal home near Oodnadatta: "Just behind the group was-well, what was it? Not a house, surely? It looked like a crazy patchwork quilt worked out in tin of all shapes, stuck together at any angle. Where there was not enough tin a row of old barrels did duty as part of the wall. It would be difficult to describe the collection of rubbish that formed the roof. This was the home of one of these native families." 39 Clearly many white middle-class women did not regard such arrangements as suitable home environments.

Thus, at the same time as many white women activists elevated white motherhood to a sacred state and used it as the basis for political action, they also represented indigenous women as unfit mothers. In recent decades, indigenous activists, writers, and scholars, as well as some non-Native scholars, have challenged and refuted such representations of indigenous people, showing them to be the simplistic stereotypes of ethnocentric reformers. While reformers perceived Native women as drudges, critics today have since recognized indigenous women's extensive physical labor as a crucial contribution to the economy of their group that endowed them with significant status. They also assert that what reformers identified as sexual immorality was in fact indigenous women exerting greater control over their own bodies and sexuality. ${ }^{40}$ Nevertheless, in the late-nineteenth and early-twentieth centuries, reformers' representations held sway and contributed to justifying state policies of indigenous child removal.

To many white women reformers, indigenous mothers had failed to fulfill their motherly role. It was thus necessary for white women to step in as surrogate mothers. The WNIA asked, "Who will carry the light to these dark sisters? Who will go to

${ }^{38}$ Annual Meeting and Report of the Women's National Indian Association (November 1884), 33-4.

${ }^{39}$ Violet E. Turner, Lazarus at the Gate (Adelaide, AUS, 1937), 32.

${ }^{40}$ For a Native author's attempt to counter such devastating stereotypes, see Ella Cara Deloria, Waterlily (Lincoln, NE, 1988), originally written in the 1940s. For scholarly works on indigenous women, see Lillian A. Ackerman, A Necessary Balance: Gender and Power among Indians of the Columbia Plateau (Norman, OK, 2003); Virginia Bergman Peters, Women of the Earth Lodges: Tribal Life on the Plains (North Haven, CT, 1995); Theda Perdue, Cherokee Women: Gender and Culture Change, 1700-1835 (Lincoln, NE, 1998); Laura F. Klein and Lillian A. Ackerman, eds., Women and Power in Native North America (Norman, OK, 1995); Diane Bell, Daughters of the Dreaming, 2nd ed. (St. Leonards, AUS, 1993); Peggy Brock, ed., Women, Rites, \& Sites: Aboriginal Women's Cultural Knowledge (Sydney, AUS, 1989). 
them and teach them of the love that can turn their night to day, their sorrow to rejoicing?" ${ }^{41}$ The answer, of course, was white Protestant middle-class women, many of whom believed, "If we do not educate Indian children to our civilized life, their parents will continue to educate them to their savagery." ${ }^{22}$ Within the schools, homes, and missions, white women would raise indigenous girls more appropriately than their own families. Ida Standley, for example, matron at the Bungalow Home for Aboriginal children in Alice Springs from 1914 to 1929, was made a Member of the British Empire upon her retirement for "spread[ing] a maternal wing about the unwanted half-castes who were in a sorry plight." ${ }^{\prime 3}$

Moreover, maternalists viewed their intervention into the lives of indigenous girls as the basis for utterly transforming Indian societies. As Reel put it: "The homes of the camp Indians are to be reached mostly through our school girls, who are to be the future wives and mothers of the race, and on their advancement will depend largely the future condition of the Indian. All history has proven that as the mother is so is the home, and that a race will not rise above the home standard." 44 Thus, white women utilized maternalism to argue for an expanded role for themselves within the public life of their nations. Yet while maternalist ideologies and politics potentially empowered white middle-class Protestant women, they served to further colonial aims by eroding indigenous women's authority within their own societies. ${ }^{45}$

This shared commitment to maternalist reform and its colonialist orientation in both the American West and Australia seems to have emanated from an Anglo-American women's internationalism that began in the late-nineteenth century and spread across English-speaking nations and colonies through the activism of the World's Woman's Christian Temperance Union (WWCTU), women's foreign missionary societies, and the Young Women's Christian Association (YWCA). 46 The WWCTU's global organizing efforts in particular brought American and Australian activists together. For example, Jessie Ackermann, an American activist who became one of the WWCTU's round-the-world missionaries, toured Australia extensively four times and

${ }^{41}$ The Indian's Friend 12 (December 1899): 10.

42 The Indian's Friend 2 (October 1889): 1.

${ }^{43}$ M.H. Ellis, "Black Australia. Alice Springs Bungalow," clipping from Adelaide Advertiser (AUS), n.d. [ca. 1924], CRS A1, 1927/2982, NA ACT.

${ }^{44}$ Quoted in "Education for Indian Girls," The Woman's Journal (19 January 1901), folder 1, box 2, Reel Papers, Eastern Washington State Historical Society, Northwest Museum of Arts and Culture, Spokane, Washington [hereafter EWSHS].

${ }^{45}$ For similar analyses, see Anderson, “Changing Woman," and Newman, White Women's Rights.

${ }^{46}$ Ian Tyrrell, Woman's World, Woman's Empire: The Woman's Christian Temperance Union in International Perspective, 1880-1930 (Chapel Hill, NC, 1991), 3, 29 and Nancy Boyd, Emissaries: The Overseas Work of the American YWCA, 1895-1970 (New York, 1986). 
claims to have organized more than four hundred branches of the WCTU there. ${ }^{47} \mathrm{Mo}-$ bilizing for suffrage worldwide, often through the WCTU as well as the International Woman Suffrage Alliance, also brought women together across international borders and allowed maternalist notions to circulate widely in disparate regions. ${ }^{48}$

In the U. S., government officials institutionalized social norms regarding maternalism by hiring many more women than men to work within the schools. David Wallace Adams found that from 1892 to 1900, of 550 Indian school teachers, 312 were women; by 1900, 286 of 347 teachers were women. In the case of Santa Fe Indian School, he found that of 69 teachers employed between 1891 and 1911, 57 were women, 45 of them single. ${ }^{49}$ The United States also developed a field matron program in 1890 by placing white women on Indian reservations to introduce middle-class domestic norms to Indian women. ${ }^{50}$ Although it was more difficult for women to gain a foothold in the upper ranks of the BIA, in 1900, out of 99 superintendents, eight were women. ${ }^{51}$

Australian women reformers seem to have had a more adversarial role with the state than American women. They often complained that the maternal voice they offered was ignored in policy-making and that women's influence was precisely what was needed when it came to indigenous affairs. Throughout the 1920s and 1930s they engaged in a sustained campaign for female protectors of Aboriginal women and children. ${ }^{52}$ Mary Bennett, for example, argued, "there is little hope for safety of the person for female natives until the evil of placing defenceless native girls under the 'protection' of alien white men is done away with, and women are appointed to care for women." 53 This campaign revealed another way in which Australian women conflicted with state authorities on Aboriginal policy; they generally objected to policies of racial absorption, of "breeding out the colour," because they believed it encouraged extramarital and interracial sex and sanctioned male sexual privilege.

${ }^{47}$ Jessie Ackermann, Australia: From a Woman's Point of View (London, 1913), 209.

${ }^{48}$ Tyrrell, Woman's World, 221-41.

${ }^{49}$ Adams, Education for Extinction, 82, 83.

${ }^{50}$ Lisa Elizabeth Emmerich, “'To Respect and Love and Seek the Ways of White Women': Field Matrons, the Office of Indian Affairs, and Civilization Policy, 1890-1938” (PhD diss., University of Maryland, 1987). Also see Emmerich's "Right in the Midst of My Own People': Native American Women and the Field Matron Program," American Indian Quarterly 15 (Spring 1991): 201-16.

${ }^{51}$ Adams, Education for Extinction, 90.

52 Paisley, Loving Protection?, 70-93; Alison Holland, "The Campaign for Women Protectors: Gender, Race and Frontier Between the Wars," Australian Feminist Studies 16 (March 2001): 27-42; Marilyn Lake, "Frontier Feminism and the Marauding White Man," Journal of Australian Studies, no. 49 (1996): 12-20. 126.

${ }^{53}$ Mary Montgomery Bennett, The Australian Aboriginal as a Human Being (London, 1930), 


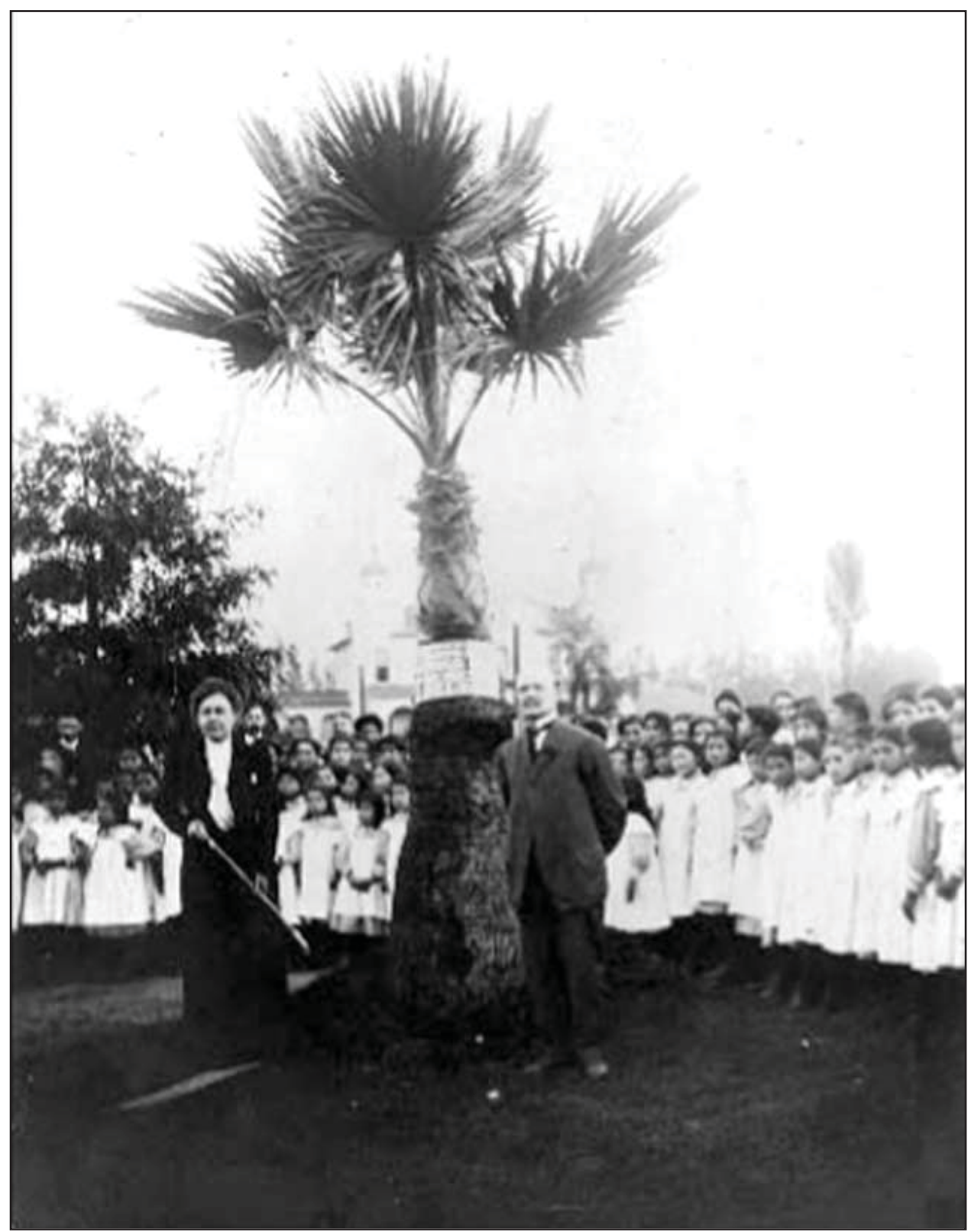

Figure 2. Estelle Reel at Sherman Institute, Riverside California, 1906. Image courtesy of Northwest Museum of Arts \& Culture, Eastern Washington Historical Society, Spokane, Washington. 
Although they often resented the interference of white women reformers, Australian male authorities typically deemed women the best caretakers for removed indigenous children. In many state-run institutions, authorities routinely hired married couples, the man to serve as superintendent of the mission, the woman as a schoolteacher. In the Northern Territory, Chief Protector Cecil Cook preferred instead to hire single women. Moreover, as in the United States, Australian administrators designated a special role for white women as "matrons" to minister to Aboriginal women. ${ }^{54}$

Within the missions that implemented many of the state's policies, Australian women played an even more pronounced role. From 1908-1937, Catherine Bishop found that the proportion of women within Australian missionary organizations varied from 58 percent to 78 percent, and that nearly all these women were single. Although most mission societies were patriarchal, two significant groups, the United Aborigines' Mission (UAM) and Aborigines' Inland Mission (AIM), were exceptions; both were "founded by women and predominantly female." 55

The state's colonial aims seemed to mesh with white women's own visions of establishing maternal colonies. In some cases, as with Estelle Reel, white women dutifully, even enthusiastically, carried out the state's colonial aims. Reel was born in Illinois in 1862, and educated in Chicago, St. Louis, and Boston. In 1886, Reel joined her brother, the mayor of Cheyenne, Wyoming, where she taught school for a few years and held local office as superintendent of schools for Laramie County. She was then elected state superintendent of schools from 1895 to 1898 . While serving in this post, Reel was also appointed secretary of the State Board of Charities and Reform of Wyoming, through which office she concentrated on improving asylums and prisons. In 1896, the Republican Party was considering her as their candidate for governor of Wyoming. Instead, she demurred and worked for the election of William McKinley. Credited with helping McKinley win the presidency, Reel was awarded with a presidential appointment to the post of superintendent of Indian education in $1898 .{ }^{56}$ Reel is unusual in gaining this position in that she did not have a long history of involvement in Indian reform; however, she seemed to quickly warm to her new position of power.

In her first three years on the job, Reel allegedly traveled 65,900 miles by train and wagon to visit Indian schools. ${ }^{57}$ During her tenure, she focused on two main efforts:

\footnotetext{
${ }^{54}$ Cook, quoted in R.H. Weddell to Dept of Interior, 19 September 1932, CRS A1, 1934/7281, NA ACT.

55 Bishop, "a woman missionary," 22.

${ }^{56}$ Biographical File, Estelle Reel, Reel Papers, WSA and Mrs. Alfred H. (Cora M. ) Beach, Women of Wyoming vol. 1 (Casper, WY, 1927), 40.

${ }^{57}$ Lori Van Pelt, “Estelle Reel, Pioneer Politician,” True West 47 (April 2000): 53.
} 
pushing for a compulsory school law for American Indian children and devising a uniform Course of Study for the Indian schools, published in 1901. In 1900, Reel asserted, "I am convinced that force is the only method to be pursued in order to uplift these people," and added, "If the Indian will not accept the opportunities for elevation and civilization so generously offered him, the strong hand of the law should be evoked and the pupil forced to receive an education whether his parents will it or not." 58

Reel believed herself to have a special feminine talent for coercing Indian women to give up their children. In one of her press releases, she asserted, "No man superintendent of Indian schools could have done what Miss Reel is doing. Her strongest hold is to go into the wigwams of the Indian women, gain their confidence and liking and make them see how much better it is to trust their children to the training of civilization.... As woman to woman she appeals to them, and they listen and acquiesce." 59

Perhaps because she was so concerned with projecting her public persona as the "Big White Squaw," Estelle Reel rarely admitted any difficulty she had in promoting the policy of Indian child removal. Once, however, she confessed in a report that the Indian mother is "much more opposed, as a rule, to allowing her children to accept the white man's civilization, than is her spouse." ${ }^{60}$ Indeed, Reel would have read the many reports from agents in the field who complained, as one did at the Mescalero Apache Reservation, that "every possible expedient was resorted to by [the women] to keep their children from school." 61

Rarely did such reports of indigenous women's objections to the removal of their children become known to the public. But one particularly vocal Indian woman, Zitkala-Ša, or Gertrude Bonnin Simmons, a Nakota (Yankton) Sioux, who had, herself, been separated from her mother to attend a series of boarding schools, grew to vehemently oppose the schools, and to use her considerable literary talent to denounce

${ }^{58}$ Report of the Superintendent of Indian Schools (Washington, DC, 1900), 15, folder 72, box 2, Reel Papers, EWSHS and Course of Study of the Indian Schools of the United States, Industrial and Literary (Washington, DC, 1901).

${ }^{59}$ Lillian Gray, "Estelle Reel: Superintendent of Indian Schools," The New Orleans Item (10 May 1903), "Articles" folder, box 1, Reel Papers, WSA. For more on Reel, see K. Tsianina Lomawaima, "Estelle Reel, Superintendent of Indian Schools, 1898-1910: Politics, Curriculum, and Land," Journal of American Indian Education 35 (Spring 1996): 5-31.

${ }^{60}$ Estelle Reel, untitled draft of article, beginning with "She believes in giving the Indian child ..." n.d., "Articles" folder, box 1, Reel Papers, WSA.

${ }^{61}$ The Indian's Friend 10 (September 1897): 10. 
them in a series of essays in The Atlantic Monthly and Harper's Magazine from 1900 to 1902. In one essay, Zitkala-Ša lamented:

For the white man's papers, I had given up my faith in the Great Spirit. For these same papers I had forgotten the healing in trees and brooks. On account of my mother's simple view of life, and my lack of any, I gave her up, also.... Like a slender tree, I had been uprooted from my mother, nature, and God. I was shorn of my branches, which had waved in sympathy and love for home and friends. The natural coat of bark which had protected my oversensitive nature was scraped off to the very quick.

Now a cold bare pole I seemed to be, planted in a strange earth. ${ }^{62}$

Zitkala-Ša's publications led Estelle Reel to protest "the unfortunate character developed in the Indian girl, Zitkala-Za [sic], who after receiving the greatest care and attention at the hands of many good missionary women and having the Government spend many thousands of dollars upon her education, has seen fit to write an article which has attracted some attention on account of its unjust character and the morbid disposition of the unfortunate girl." 63

Of the white women featured in this article, Reel seems to have most closely adhered to and carried out the government's aims, perhaps because she had not been involved in Indian reform efforts prior to her appointment as superintendent of Indian education. At the close of her career in the federal government, Reel seems never to have been involved in Indian reform again. In 1910, she married Cort Meyer of Toppenish, Washington. Thereafter, "Mrs. Meyer's zeal was transferred to beautifying her home," according to the obituary written on her death at age 96 in $1959 .{ }^{64}$ As an official, Reel remained distant and removed from the day-to-day workings of the policy she promoted and did not seem to have experienced any regret or remorse about her work. If Reel did feel any ambivalence about Indian child removal, she did not reveal it the papers that she left to posterity. Ironically, Reel's papers only give us the official story; perhaps because of her lifelong attempt to control her public image, her papers are silent as to what meaning Reel gave to her participation in the colonial project.

Interestingly, it is from the more personal records of other white women that we may gain a greater understanding of the intimacies of empire, at least from a white woman's point of view. Annie Lock did not leave large collections of personal papers;

${ }^{62}$ Zitkala-Ša, American Indian Stories (Lincoln, NE, 1985), 97. This quote originally appeared in Zitkala-Ša, "An Indian Teacher Among Indians," Atlantic Monthly 85 (March 1900): 386.

${ }^{63}$ Reel, "She believes in giving the Indian child ..."

64 "Death Takes Mrs. Cort F. Meyer at Age of Ninety-six," Toppenish Review, 6 August 1959, Biographical File, Estelle Reel, Reel Papers, WSA. 
instead her letters and reports are scattered throughout a number of missionary publications and archival collections throughout Australia, many of them gathered together in Catherine Bishop's excellent master's thesis on Lock. Lock, who was more intimately involved with indigenous child removal than Reel, yet more marginalized from positions of state authority, seemed to develop more ambivalence about carrying out colonial policies. Born in 1876, Annie Lock had been working as a dressmaker in Riverton, South Australia, when, at age 24, she "received her call." After training as a missionary, Lock worked with the United Aborigines' Mission for many decades among a number of different aboriginal groups in Australia. ${ }^{65}$

Imbued with a sense of maternal colonialism, Lock did not shy away from removing indigenous children from their families. For example, in 1910, when she worked at the Dulhi Gunyah orphanage in Western Australia, Annie Lock wrote that she had learned of "neglected [Aboriginal] children at Busselton." "On the following day," she wrote, "I consulted several members of the Council, when a course of action was decided upon, the outcome of which has been several additional children handed over to us for training." A few days later she reported that she had visited Busselton and brought home "eight additional inmates, one a baby about twelve months old." ${ }^{\prime \prime 6}$ Note that when referring to Aboriginal children, Lock utilized a language that obscured the true horror of the enterprise in which she was engaged. Children were "inmates," "a course of action was decided upon"; children "came" were "handed over" or "were received" by Lock and the orphanage.

After twenty-four years of working among various Aboriginal groups, in 1927 Lock struck out on her own for Harding Soak, about one hundred miles north of Alice Springs in Central Australia, where she worked among the Kaitish and Unmatjera groups and became embroiled in a conflict over the removal of two Aboriginal girls, Dolly and Betsy. ${ }^{67}$ During her first six months there, Lock nursed a diseased Aboriginal man who had shown up at camp with two Aboriginal women and their children, including one "halfcaste" girl known as Dolly. According to Lock, Dolly's mother gave the child to Lock. Lock also treated another Aboriginal man's arm and took in his baby, Betsy. ${ }^{68}$ When her two adult patients had healed, Lock moved to minister among the Aboriginals at Barrow Creek. "When I left Harding Soak the mother was there and wished Dolly goodbye,"

${ }^{65}$ Violet E. Turner, The "Good Fella Missus" (Adelaide, AUS, 1938), 6; Max Cartwright, Missionaries, Aborigines and Welfare Settlement Days in the Northern Territory (Alice Springs, AUS, 1995), 1-2; Bishop, "a woman missionary," 12-5.

${ }^{66}$ Quoted in Bishop, “a woman missionary,” 179, 180.

${ }^{67}$ Annie Lock to Mr. Sexton, 1 June 1927, State Record Group (SRG) 139/1/102, Aborigines' Friends Association Papers, Mortlock Library, South Australia, AUS. See also, Cartwright, Missionaries, Aborigines and Welfare Settlement Days, 2-4.

${ }^{68}$ Report by Annie Lock, 25 November 1928, CRS A1/15, 1929/984, NA ACT. 


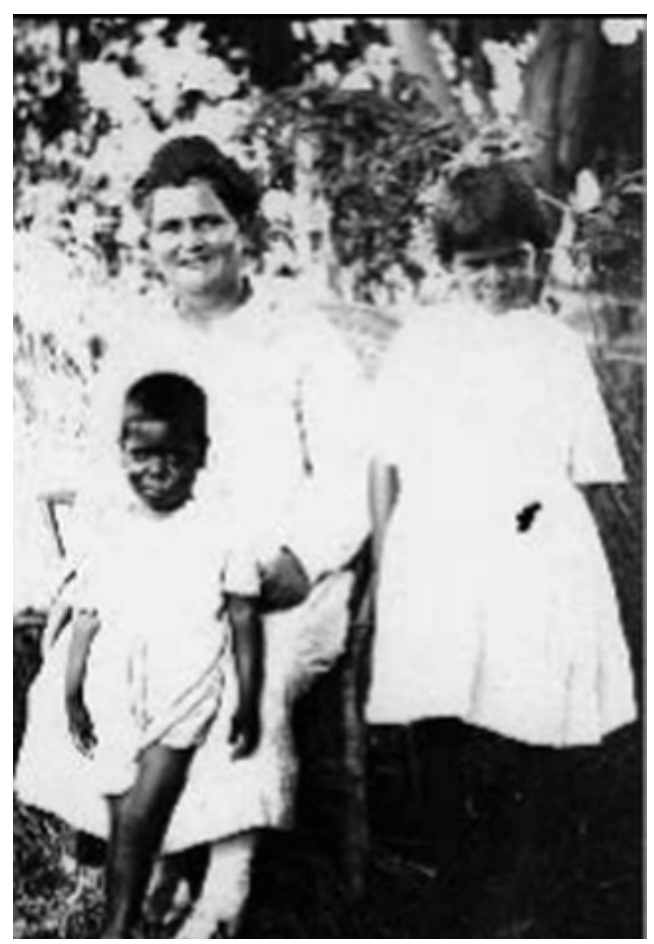

Figure 3. Annie Lock with "Dolly" and "Betsy," Darwin, 1928. Courtesy of the National Archives of Australia, A1, 1929/984.

Lock later asserted, "and said, 'bring her back to see me when she is big girl." When she arrived at Barrow Creek, Lock claims that "the officials had sent the natives out bush, because they were killing [white settlers'] stock." Lock decided to continue north to Darwin with the girls, in part to help Dolly and Betsy find treatment for a disease called yaws. ${ }^{69}$

Although Lock presented Dolly's and Betsy's parents as voluntarily giving them to her, government authorities reported otherwise. J. C. Cawood, government resident in Central Australia alleged that an Aboriginal woman had complained that Lock had taken her child, presumably Betsy. ${ }^{70}$ Sergeant R. Stott, police protector of Aboriginals in Central Australia, claimed that Dolly's mother "requested Dolly be taken to the Halfcaste Home at Alice Springs." According to Stott, Lock "very much resented the Mothers [sic] wish." When Stott informed Lock that the "Halfcaste home was the proper place for Dolly.... [the girl] commenced crying and clinging to Ms. Locks [sic] dress." Lock told Stott "it was her desire to adopt Dolly and take her to Quorn," in South Australia, and she asked Stott to be allowed her to keep the girl. He "agreed to leave Dolly temporary [sic] in her charge."71

At the same time as Lock clashed with authorities and Aboriginal families over the fate of Dolly and Betsy, other conflicts were engulfing Central Australia. When Lock arrived in the area, a severe drought had been devastating the area for nearly four years. Moreover, white settlers were driving Aboriginal people from their traditional hunting grounds and waterholes. Lock became an outspoken critic of the settlers and the government who sanctioned their actions. In July of 1928, she wrote to a friend, "The poor natives are just hunted from their hunting grounds and cannot get their usual food. Where they used to camp near waterholes and wait for their wild animals to come in

${ }^{69}$ Ibid.

${ }^{70}$ R. Stott to J.C. Cawood, Government Resident, 2 March 1928, CRS A1/15, 1929/984, AA ACT.

${ }^{71}$ Ibid. 
for water, now these waterholes are taken up by the squatters for their cattle and sheep." Lock understood why the Aboriginals with whom she lived resorted to raiding settlers' camps for livestock: "[T]hey do not like to see their little ones dying and crying for food." Lock further blamed the government, which received "rent from these squatters and [did] not give the natives food in place of their country." 72

Just over a month after Lock wrote this letter, a white dingo hunter near Coniston Station had taken an Aboriginal woman from her camp and refused to return her. On 7 August, this man was found dead, his mutilated body stuffed into a rabbit hole. In retaliation, the police, led by Constable George Murray, and other local whites massacred at least thirty-four Aboriginals in the area and arrested two Aboriginal men, Padygar and Arkirtra, for the white man's murder. At almost the same time as Lock was traveling north with Dolly and Betsy, Constable Murray was escorting his two prisoners to Darwin for trial. In Darwin with Dolly and Betsy, Lock attended the trial of Padygar and Arkirtra, who were acquitted for lack of evidence. ${ }^{73}$

At this point, male government authorities from Central Australia accused Lock of taking Dolly without the mother's consent and ordered Constable Murray to take the children into his custody. When he tried to do so, Lock confronted him at the Railway Station in Darwin. As Lock hugged Dolly and Betsy to her, the constable demanded that Lock return the children. According to newspaper reports, Lock exclaimed, "Take them, but take them from my arms!" The constable responded that it was his duty to do so. Lock retorted, "Duty! I did your duty for you. I rescued a starving, motherless babe suffering from sores, ... right under your very nose." Newspapers reported that a sizable crowd had gathered in sympathy with Lock. The constable decided not to press the issue, and "Lock bore away her charges amid cheers." ${ }^{74}$

However, the case did not end in Lock's triumph. Lock was summoned back to Central Australia to give evidence to a board of inquiry that was investigating the Coniston massacre. The board found "no provocation" by whites for Aboriginal depredations and no evidence of police misconduct. Instead, it blamed the "rising of the natives" on "unattached missionaries wandering from place to place having no previous knowledge of blacks and their customs and preaching a doctrine of equality." Further the board impugned Lock as a "woman missionary living amongst naked blacks thus lowering their respect for the whites." The police were exonerated

${ }^{72}$ Annie Lock to Miss Evans, 1 July 1928, CRS A1/15, 1929/984, NA ACT.

${ }^{73}$ Cartwright, Missionaries, Aborigines and Welfare Settlement Days, 5-7 and Turner, Good Fella Missus, 32, 36-8. For more on the Coniston Massacre, see John Cribbin, The Killing Times: The Coniston Massacre 1928 (Sydney, AUS, 1928) and Bruce Elder, Blood on the Wattle: Massacres and Maltreatment of Aboriginal Australians since 1788, 3rd ed. (Sydney, AUS, 2003).

74 "Grim Struggle for Abo. Girls," Labor (Sydney, AUS) Daily, 19 November 1928 and "Crowd Objects to Police Taking Abo. Children," (Sydney, AUS) Guardian, 19 November 1928. Both clippings in CRS A1/15, 1929/984, NA ACT. 
and the newspapers covered the sensational charges against Lock rather than the violent raids that had been conducted against Aboriginal people in the area. ${ }^{75}$ For taking Dolly and Betsy from Central to North Australia without state permission, authorities fined Lock three pounds and five shillings. The state took Dolly into custody and put her in the Bungalow Home in Alice Springs. They left Betsy in Lock's care, presumably because she was "full-blooded," not "half-caste," but refused Lock permission to take the girl with her to Adelaide. ${ }^{76}$

In their battle with Lock, government authorities portrayed themselves as defenders of a poor Aboriginal mother whose child had been torn from her. Constable Murray asserted that "suitable action be taken to have the [Aboriginal] child [Betsy] returned to its [sic] mother, the mother is very grieved over the loss of her child." 77 Of course, many officials routinely removed Aboriginal children from their mothers without a thought for the mothers' grief. What really seemed to be at issue was that authorities resented Lock's outspoken condemnation of colonial policies and practices. ${ }^{78}$ On her own part, Lock positioned herself as the wronged mother. Effacing the Aboriginal mothers whom she had dispossessed of their children, Lock represented herself at the Darwin railway station as the victimized mother whose children were being taken from her. Left out of the equation altogether were the Aboriginal mothers of Dolly and Betsy.

Lock moved on in 1933 to minister to Aboriginals at Ooldea in South Australia, where she continued to participate in efforts to remove Aboriginal children from their families. At one point she revealed, "The past two months we have had trouble with the young girls.... The adults have tried to get them away. One went away, but returned; two of the girls, Pansy \& Dossie, again ran away, but were brought back." ${ }^{79}$ In 1937 , at the age of sixty, after 34 years of working as a missionary among Aboriginals, Lock married James Johansen. The new couple acquired a caravan, which they used to conduct itinerant mission work. Lock died just seven years later in $1943 .{ }^{80}$

Lock's case, particularly, reveals the fissures that could develop in the edifice of colonial control as white women became involved in carrying out the aims of colonial authorities. Although Lock did support child removal, she became critical of other aspects of colonial policy, and, indeed, believed herself more capable of "rescuing" and "saving"

75 Turner, Good Fella Missus, 44-51, quotes from 48, 50, 51; Cartwright, Missionaries, Aborigines and Welfare Settlement Days, 9-13; Bishop, "a woman missionary," 126-30.

${ }^{76}$ Annie Lock to Mary Bennett, August 1929, GRG 52/32/31, SRSA. See also Turner, Good Fella Missus, 51.

77 George Murray to "Sir," 19 October 1928, CRS A1/15, 1929/984, NA ACT.

${ }^{78}$ Cartwright, Missionaries, Aborigines and Welfare Settlement Days, 5-7, 9-13; Turner, Good Fella Missus, 32, 36-8, 44-51; Bishop, "a woman missionary," 126-30.

${ }^{79}$ Quoted in Bishop, "a woman missionary," 268.

${ }^{80}$ Ibid., 34-7, 95-6, quote 36, 270; Cartwright, Missionaries, Aborigines and Welfare Settlement Days, 1, 21; Violet E. Turner, Ooldea (Melbourne, AUS, 1950), 4-36. 
Aboriginal children than state authorities. Other accounts by white women missionaries and schoolteachers in both the American West and Australia reveal that through sustained contact and interaction with indigenous children, and the communities from which they came, white women sometimes developed a more critical attitude toward colonialism, even as they often continued to support child removal.

Only a very small number of white women broke away from their maternalist sisters to become outspoken critics of indigenous child removal and to connect it with other colonial practices. In 1900, novelist Constance Goddard DuBois, a member of the Connecticut Indian Association, a branch of the WNIA, vehemently condemned Reel's proposed compulsory education law. "We have robbed the Indians, persistently, systematically, under process of law, and without law," DuBois wrote, "but never has there been such bitter robbery as this. They have been driven by force, like herds of cattle, from the lands the white man coveted; yet even then the Indian mother might keep her child if only to see it die within her arms." ${ }^{81}$ Asserting that the law would "turn the Indians into a scattered remnant of homeless vagrants, cheap laborers, or paupers, without land," DuBois developed a sophisticated analysis of child removal as a component of colonialism. Moreover, she called for equal treatment for Indians under the law. "No white child can be forcibly carried from his home without the consent of his parents," wrote DuBois, "taken to a school inaccessible and remote, and kept a prisoner under close restraint during the term of his education." DuBois agreed that Indians should be provided with education, but insisted that "the school should be brought to the Indian, not the Indian to the school." ${ }^{2}$

Mary Bennett, who for many years worked at the Mt. Margaret Mission in Western Australia, came to share both DuBois's vehement opposition to the removal of indigenous children and her critique of maternal colonialism. In 1937, Bennett implored other white women

NOT to condone or justify taking half-caste children from their aboriginal mothers. The unfortunate mothers are only victims of starvation and to separate parents and children is to destroy both in the most cruel way.... The recent Land Act Amendment of W[estern] A[ustralia] takes away from natives the right to hunt over their tribal lands when these are enclosed, and ... all the native waters are fenced in [by] the [white] squatters.... Their game is destroyed and their dogs are destroyed and the only way they can come by a meal is by selling their women. So I say that W. A. is deliberately starving their natives to death in their own country. ${ }^{83}$

${ }^{81}$ Constance Goddard DuBois, "A New Phase of Indian Education," City and State 7 June 1900, p. 363, folder 30, Newspaper Clippings, box 1, Reel Papers, EWSHS.

${ }^{82} \mathrm{Ibid}$. As far as I can tell, DuBois was successful in preventing the passage of this law.

${ }^{83}$ Mary Bennett to Olive Pink, 12 September 1937, I. F. (a) (2), Olive Pink Papers, Australian Institute for Aboriginal and Torres Strait Islander Studies, Canberra, AUS. 
By the 1920s in the U. S. and the 1930s in Australia, other white women had begun to join DuBois and Bennett in challenging the policies of indigenous child removal. While it is beyond the scope of this article to trace this development, I contend that it was only after they had abandoned maternalist politics, and its attendant views of indigenous women as "daughters" in need of uplift, that white women activists were able to develop a straightforward opposition to indigenous child removal. Maternalist politics, though professing a concern and sisterhood with all women, did not promote equality between women, but reaffirmed class, racial, and religious hierarchies. Ironically, white women maternalists who sought to use their association with motherhood to gain greater power in society were simultaneously engaged in dispossessing indigenous mothers of their children. In challenging the ascendancy of maternalism, women such as DuBois and Bennett became fierce critics of the colonial policies and practices of their governments and identified the ways in which colonialism had invaded even the most intimate spaces of indigenous people's lives. Western women's historians have the opportunity to follow the lead of DuBois and Bennett: to develop a critical analysis of maternalism and to examine the intricate workings of gender and colonialism in the intimacies of empire. 